\title{
Factors that drive zooplankton diversity in Neo-Tropical Savannah shallow lakes
}

\author{
Fatores que determinam a diversidade de zooplâncton em lagoas rasas de \\ Savana Neo-Tropical
}

\section{Claudia Padovesi-Fonseca ${ }^{1 *}$ and Renan de Souza Rezende ${ }^{1,2}$}

\author{
${ }^{1}$ Departamento de Ecologia, Instituto de Biologia, Universidade de Brasília - UnB, Campus \\ Universitário Darcy Ribeiro, CEP 70910-900, Brasília, DF, Brazil \\ ${ }^{2}$ Programa de Pós-graduação em Ecologia e Conservação, Universidade Federal Rural do Semiárido \\ - UFERSA, Av. Francisco Mota, 572, Costa e Silva, CEP 59625-900, Mossoró, RN, Brazil \\ *e-mail: padovesi@unb.br
}

Cite as: Padovesi-Fonseca, C. and Rezende, R.S. Factors that drive zooplankton diversity in Neo-Tropical Savannah shallow lakes. Acta Limnologica Brasiliensia, 2017, vol. 29, e15.

\begin{abstract}
Zooplankton is an important community in aquatic ecosystems due to its linkage between primary producers and secondary consumers also playing a key role in cycling of organic materials. Aim: Therefore, our objective was to evaluate the effects of physicochemical variables of the water on the diversity of zooplankton community in seven tropical shallow lakes of Brazilian savannah. Methods: Zooplankton samples were taken using a bucket and filtered $200 \mathrm{~L}$ by a $64 \mu \mathrm{m}$-mesh-plankton-net, and preserved for subsequent identification. Water temperature, dissolved oxygen, $\mathrm{pH}$, electrical conductivity, turbidity, chlorophyll- $a$, ammonium, nitrate, nitrite, total phosphorus, and soluble reactive phosphorus were measured. Results: The turbidity (decreases the temperature, luminosity and the system productivity) and ammonium (increases the toxicity) values were the major factors responsible for structuring the zooplankton community. On the other hand, also nitrogen and phosphorus (increase the productivity) are limiting in savannah lentic systems for the zooplankton. The higher $\alpha$ diversity was positively associated with aquatic macrophytes (increase of niches and refuge), whereas lakes with geographic proximity increase the similarity in species composition, decreasing the $\beta$ diversity. Conclusions: We conclude that the deterministic processes (niche theory), due to species have different ecological requirements, are different responses to environmental gradients and increase the diversity in heterogenic lentic systems.
\end{abstract}

Keywords: $\alpha$ diversity; $\beta$ diversity; nutrients; habitat heterogeneity; lentic systems.

Resumo: O zooplâncton é uma comunidade importante nos ecossistemas aquáticos por ser o elo entre os produtores primários e os consumidores secundários, além de desempenharem um papel fundamental no ciclo de materiais orgânicos. Objetivo: Nosso objetivo foi avaliar os efeitos das variáveis físicas e químicas da água na diversidade de zooplâncton em sete lagoas rasas tropicais da savana brasileira. Métodos: As amostras de zooplâncton foram coletadas usando balde e filtrando 200 litros em rede de plâncton com abertura de $64 \mu \mathrm{m}$, e preservadas para posterior identificação. A temperatura da água, oxigênio dissolvido, $\mathrm{pH}$, condutividade elétrica, turbidez, clorofila-a, amônio, nitrato, nitrito, fósforo total, fósforo reativo solúvel, cobertura de macrófita da lamina d'água foram obtidos. Resultados: A turbidez (ao diminui a temperatura, a luminosidade e a produtividade do sistema) e os valores de amônio (por aumenta a toxicidade) foram os principais fatores responsáveis pela estruturação do zooplâncton. Por outro lado, o nitrogênio e o fósforo (por aumentar a produtividade) são limitantes para o zooplâncton nos sistemas lênticos de savana. A maior diversidade $\alpha$ foi associada 
positivamente com macrófitas aquáticas (devido ao aumento de nichos e refúgio), enquanto que lagos com maior proximidade geográfica aumentou a similaridade na composição das espécies, e diminuindo a diversidade de $\beta$. Conclusóes: Os processos determinísticos (teoria do nicho), por haver muitas espécies com diferentes requisitos ecológicos, apresentaram respostas diferentes aos gradientes ambientais e foram responsáveis por aumento da diversidade em sistemas lêntico mais heterogênios.

Palavras-chave: diversidade $\alpha$; diversidade $\beta$; nutrientes; heterogeneidade de habitat; sistemas lênticos.

\section{Introduction}

Tropical wetlands have played an important role for human commodities such as water storage, ground water recharge, water purification, recreation and ecotourism (Dudgeon et al., 2006; Allan, 2007). The wetlands have a large number of niches and higher species richness, due to its productivity comparable to rainforests and coral reefs (Kumar et al., 2011). However, the aquatic ecosystems face several environmental impacts (Xiong et al., 2016), mostly generated by anthropogenic activities, leading to changes in the physical habitat and jeopardizing biodiversity (Allan, 2004, 2007). This highlights the importance of its study to understand the functioning of these ecosystems and help in public policies for biodiversity conservation in lentic systems, such as shallow lakes.

Shallow lakes represent a common physiographic element showing high biodiversity in tropical systems (Kumar et al., 2011). This biodiversity (distribution and composition) of aquatic communities (e.g. insects, fungi, fishes, zooplankton and phytoplankton) can be determined by environmental factors (e.g. decrease of diversity by water pollutants) and through their biological relationship (e.g. predation and competition) (Grenouillet et al., 2008; Nessimian et al., 2008). Among the aquatic communities, zooplankton is important because it is the link between primary production (phytoplankton and bacterioplankton) to secondary consumers (e.g. fish and macroinvertebrates) and play a key role in cycling of organic materials in an aquatic ecosystem (Kozlowsky-Suzuki \& Bozelli, 2002; Matsumura-Tundisi \& Tundisi, 2005; Norlin et al., 2006).

Studies has been performed in different time intervals, as the interannual (Lansac-Tôha et al., 2009), monthly (Ortega-Mayagoitia et al., 2000; Fantin-Cruz et al., 2010), and/or weekly variation cycle (Chittapun et al., 2009), derived from the different sampling frequencies of the zooplankton in various types of wetlands (Bottrell et al., 1976; Guseska et al., 2012). The zooplankton species also have high sensitivity to environmental impacts which can lead to changes in the composition and diversity of this community (Xiong et al., 2016), Therefore, the zooplankton community modification can help to understanding the mechanisms that structure the aquatic environment (Almeida et al., 2009; Xiong et al., 2016).

In Brazil, some zooplankton studies have been done in lakes from Amazon in the northern region (Bozelli, 1992; Hardy, 1992), São Francisco river basin in the northeastern region (López \& Sampaio, 2000), Pantanal in the central region (Fantin-Cruz et al., 2011) and Paraná river in the southern region (Lansac-Tôha et al., 2009). Thus, due to high environmental heterogeneity we could get a different composition and diversity in the zooplankton communities (Carvalho et al., 2001), along this gradient. As example, hydrological features (e.g. depth, transparency and capacity of the reservoir) can drive their limnological patterns (e.g. electrical conductivity, $\mathrm{pH}$ and dissolved oxygen) and further influence some processes (e.g. precipitation, winds and land uses), change these communities and its diversity in the landscape (De Paggi \& Paggi, 2008).

The neo-tropical savannah (Cerrado) has countless number of natural shallow lakes formed into wetlands areas by the upwelling of the groundwater (Fonseca et al., 2014). Studies done in these lentic systems have been scarce, despite their potential to increasing aquatic biodiversity in Brazilian savannah have been reported (Leibowitz, 2003), especially in protected areas with a pristine condition. This high variability on characteristics of aquatic environments has led to the recent studies on the alpha (number of species) and beta (species composition turnover among communities) diversity (Bini et al., 2014; Lopes et al., 2014; Heino et al., 2015a, b). However, the lakes situated in Brazilian savannah (general characteristics) tend to be shallow, with transparent water and a dense bank of macrophytes, including a rich submerged and floating flora (Junk et al., 2014), but poor in nutrients (Fonseca et al., 2014). Therefore, our hypothesis is that i) shallow lakes systems that are more heterogeneous in their environmental 
conditions and nutrients concentration would have higher diversity; and ii) larger distances between lakes communities increase the values of beta diversity. Therefore, the objective of the present study was to evaluate the effects of physicochemical variables of the water on the diversity of zooplankton community in seven tropical shallow lakes of Brazilian savannah.

\section{Material and Methods}

\subsection{Study area}

This study was carried out in the seven natural shallow lakes located in Federal District and state of Goiás, central Brazil. These shallow lakes are: Feia, Bonita, Joaquim Medeiros, Carás, Taquara, Gansos and Cedro (Figure 1). The Feia lake is located in the São Francisco basin and Bonita lake in Tocantins basin, the others are located in the Paraná basin. The Cerrado Domain (Brazilian savannah) covers the region. Climate is Aw (rainy tropical, according to Köppen classification), marked by a rainy season from October to April (mean temperature around $29^{\circ} \mathrm{C}$ ), and a dry season from May to September (mean temperature around $18^{\circ} \mathrm{C}$ ). Annual mean precipitation is around $1,500 \mathrm{~mm}$, ranging from 750 to $2,000 \mathrm{~mm}$.

These natural shallow lakes are formed by the upwelling of groundwater. The six oligotrophic shallow lakes situated in Federal District are shallow (depth $\leq 3$ meters), small (surface area $\leq 1 \mathrm{~km}^{2}$ ), with slightly acid waters and abundant aquatic macrophytes. Bonita lake is situated in permanent protection area (Ecological Station of Águas Emendadas); the others are situated on rural areas. Feia lake is the only urban located inside the Park Mata da Bica (Formosa, state of Goiás). This lake is deeper (max 10 meters) and larger $(300 \mathrm{~m}$ width; $6 \mathrm{~km}$ length) than the previous shallow lakes.

\subsection{Sampling}

Water and zooplankton samplings were carried out between 2008 and 2009, in the dry (August-September 2008) and rainy (March-April, 2008 and 2009) seasons. Water temperature, dissolved oxygen, $\mathrm{pH}$, and electrical conductivity were measured in the field using standard electrodes (Yellow Spring Instruments). Water samples were collected in previously acid-washed polypropylene bottles and kept in a cooler until returning to the laboratory. Nutrients (ammonium $\mathrm{NH}_{4}^{+}$, nitrate $\mathrm{NO}_{3}^{-}$, nitrite $\mathrm{NO}_{2}^{-}$, total phosphorus, and soluble reactive phosphorus, DIN - dissolved inorganic nitrogen, TKN - total Kjeldahl nitrogen), total dissolved solids, and alkalinity were analyzed according to standard methods. Turbidity was measured using a turbidimeter $\mathrm{HACH} 2100 \mathrm{P}$. The percentage of lake covered by macrophytic was visually estimated by classifying into four possible categories (0-25\%, 25-50\%, 50-75\% and 75-100\%).

For chlorophyll-a determinations 500 to $1,000 \mathrm{~mL}$ nonfractionated whole water were filtered through Whatman $47 \mathrm{~mm}$ GF/F glass fiber filters $(0.7 \mu \mathrm{m})$ under vacuum $(<120 \mathrm{mmHg})$. Sampling filtration was performed in duplicate and immediately was made the specimens selection to minimize any potential grazing effects. The filters were placed in dark test tubes pre-filled by $10 \mathrm{~mL}$ extraction solution (acetone 90\%). After storage for 12 hours in a refrigerator, the absorbance of the acetone extract was measured at specific wavelengths (750 and $665 \mathrm{~nm}$ ) with a Hitachi model 100-60 double beam spectrophotometer using $1 \mathrm{~cm}$ glass cuvettes.

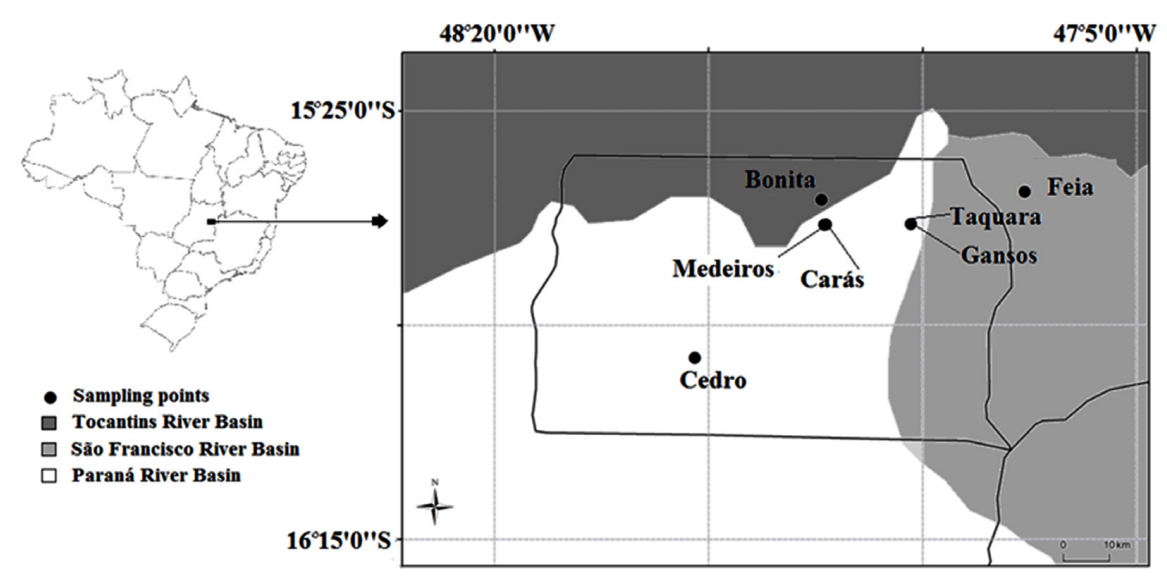

Figure 1. Geographic location of the sampling points consisting of seven shallow lakes in Federal District (Brazil). 
Zooplankton samples were taken using a bucket and filtered $200 \mathrm{~L}$ by a $64 \mu \mathrm{m}$-mesh-plankton-net, and preserved in formalin solution ( $4 \%$ final concentration). Organisms were identified using an optical microscope and specialized bibliography (Koste, 1978; Segers, 2007; Elmoor-Loureiro, 2007). Specimens were deposited in the Laboratory of Limnology at the University of Brasília (UnB-DF), Federal District, Brazil.

\subsection{Measuring the diversity index}

Based on the mean of density of organisms collected for each sampling points, the Shannon-Wiener index, Simpson index and Pielou's Evenness index were also calculated (Magurran, 2001; Ferreira et al., 2011). The number of invertebrates' taxa at all sampling points was used to estimate the $\alpha$ diversity. We estimated the $\beta$ diversity with the multivariate dispersion method (Anderson et al., 2006). Multivariate dispersion (functions betadiver, Vegan package for $\mathrm{R}$ version 2.0.8; Oksanen et al., 2008) estimates the $\beta$ diversity as sampling points average dissimilarity (i.e., distance) from their group centroid in a multivariate space. The comparison among sampling points was based on the Whittaker index ( $\beta$ w; Whittaker, 1960; Magurran, 2001) as proposed by Koleff et al. (2003). According to Koleff et al. (2003), $\beta \mathrm{w}$ is the most widely used $\beta$ diversity measure in Ecology and the values show a simple relation to variation in that whole scale negatively with increase in the matching component.

\subsection{Statistical analysis}

The normality of the biological variables was tested using a Kolmogorov-Smirnov test, and the variables were transformed as necessary $(\log 10 \mathrm{x}+1)$. The density and number of taxa in zooplankton community among sampling points was tested with One-way ANOVA (Zar, 1996). We used the Newman-Keuls test $(p<0.05)$ for discrimination among the categorical variables (Zar, 1996) to estimate the difference in the structure and composition of zooplankton community and $\beta$ diversity (different axes related to the distance from the centroid) among the sampling points, a Permutational Multivariate Analysis of Variance (PerMANOVA), discriminated by Bonferroni-corrected pairwise comparison (distance matrix of Bray-Curtis, 10000 permutation and with pseudo-F; Adonis function, vegan package for R; Oksanen et al., 2008).
A Canonical Correspondence Analysis (CCA) was used to detect variations in community composition along the environmental gradient and to identify potential environmental requirements to differentiate the assemblages (function CCA; Legendre \& Legendre, 1998). The statistical significance of the correlation between the environmental features and biotic variables extracted from the CCA was determined by a Monte Carlo test based on 5,000 permutations $(\mathrm{P}<0.05)$.

An analysis of the indicator species, as proposed by Dufrêne \& Legendre (1997), was used to determine which organisms were characteristic of the sampling points. This analysis uses the frequency and density of the organisms in the previously defined groups and produces an indicator value ranging from 0 (non-indicator) to 100 (perfect indicator). Significance was tested using Monte Carlo tests with 1000 permutations and set to $\mathrm{P}<0.05$. Only significant results are reported.

\section{Results}

\subsection{Water physical and chemical parameters}

The higher values of water temperature, dissolved oxygen and $\mathrm{pH}$ were found in Carás lake. On the other hand, Feia lake shows a higher values of electric conductivity, nitrate, TDS and DIN; and Medeiros lake to turbidity and ammonium (Table 1). Overall, the seven shallow lakes show a circumneutral water, with low levels of oxygen, electrical conductivity, alkalinity and nutrients concentration (Table 1).

\subsection{Diversity of zooplankton community}

A total of 4,964 individuals (org. $\mathrm{m}^{3}$ ) was collected in this study, with the higher values (One way ANOVA, $\mathrm{F}_{(6,28)}=4,64 ; \mathrm{p}=0.025$ ) in Bonita lake (mean of 1605 org. $\mathrm{m}^{3}$ ), following by (Newman-Keuls test; $\mathrm{p}<0.05$ ) Carás lake (mean of $705 \mathrm{org} \cdot \mathrm{m}^{3}$ ), Cedro lake (mean of $\left.684 \mathrm{org} \cdot \mathrm{m}^{3}\right)$, Gansos lake (mean of $661 \mathrm{~m}^{3}$ ), Feia lake (mean of $462 \mathrm{org} . \mathrm{m}^{3}$ ), Taquara lake (mean of $422 \mathrm{org} . \mathrm{m}^{3}$ ) and Joaquim Medeiros lake (mean of 420 org. $\mathrm{m}^{3}$ ). The most abundant taxon was the Calanoida, followed by Chydorus, manly in Bonita and Cará lakes, respectively.

The Shannon-Wiener and the Simpson (Figure 2A and B) indexes show the same pattern, with the higher values in Gansos lake following by Bonita lake, Feia lake and Carás lake, up the mean among all sampling points, but show lower values in Cedro lake, Medeiros lake and Taquara lake, down the mean among all sampling points. 
Table 1. Mean and standard deviation values of the environmental variables in seven tropical shallow lake of Brazilian savannah.

\begin{tabular}{|c|c|c|c|c|c|c|c|c|c|}
\hline & 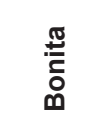 & 茪 & $\begin{array}{l}\text { 윻 } \\
\text { U⿺ }\end{array}$ & 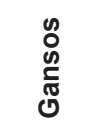 & 需 & 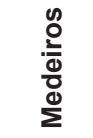 & $\begin{array}{l}\frac{\pi}{\frac{\pi}{\pi}} \\
\frac{\pi}{\frac{\pi}{\sigma}} \\
\frac{\sigma}{6}\end{array}$ & 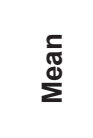 & के $\frac{\frac{\pi}{2}}{\frac{0}{\partial}}$ \\
\hline Water $\mathrm{T}^{\circ} \mathrm{C}$ & 27.03 & 30.10 & 26.95 & 26.40 & 25.05 & 28.85 & 23.75 & 26.88 & 2.15 \\
\hline Dissolved oxygen (mg/L) & 4.84 & 5.11 & 4.96 & 4.52 & 4.22 & 4.55 & 5.03 & 4.75 & 0.33 \\
\hline $\mathrm{pH}$ & 6.48 & 7.43 & 6.74 & 6.13 & 5.27 & 7.09 & 7.14 & 6.61 & 0.74 \\
\hline Elec.conductivity $(\mu \mathrm{S} / \mathrm{cm})$ & 6.55 & 27.45 & 23.08 & 11.50 & 147.50 & 65.73 & 16.95 & 42.68 & 50.12 \\
\hline Chlorophyll & 7.42 & 112.55 & 3.21 & 8.42 & 3.51 & 14.46 & 1.88 & 21.64 & 40.32 \\
\hline Turbidity (UT) & 3.84 & 6.25 & 4.07 & 8.46 & 5.32 & 10.92 & 5.32 & 6.31 & 2.55 \\
\hline Ammonium (mg/L) & 0.05 & 0.18 & 0.13 & 0.15 & 0.15 & 0.97 & 0.07 & 0.24 & 0.32 \\
\hline Nitrate $(\mathrm{mg} / \mathrm{L})$ & 0.06 & 0.18 & 0.05 & 0.05 & 0.33 & 0.20 & 0.05 & 0.13 & 0.11 \\
\hline Nitrite $(\mathrm{mg} / \mathrm{L})$ & 0.01 & 0.00 & 0.01 & 0.01 & 0.01 & 0.76 & 0.01 & 0.11 & 0.28 \\
\hline Total.Nitrogen (mg/L) & 6.18 & 2.27 & 6.54 & 5.23 & 4.51 & 6.09 & 3.99 & 4.97 & 1.51 \\
\hline Total.Phosphorus (mg/L) & 0.01 & 0.03 & 0.01 & 0.02 & 0.01 & 0.03 & 0.01 & 0.02 & 0.01 \\
\hline TDS & 2.40 & 2.50 & 8.93 & 2.80 & 49.60 & 15.67 & 5.07 & 12.42 & 17.08 \\
\hline DIN & 0.12 & 0.36 & 0.19 & 0.15 & 0.48 & 1.92 & 0.13 & 0.48 & 0.65 \\
\hline Macrophyte (\% lake covered) & 75.00 & 25.00 & 25.00 & 75.00 & 25.00 & 50.00 & 25.00 & 37.50 & 13.36 \\
\hline
\end{tabular}

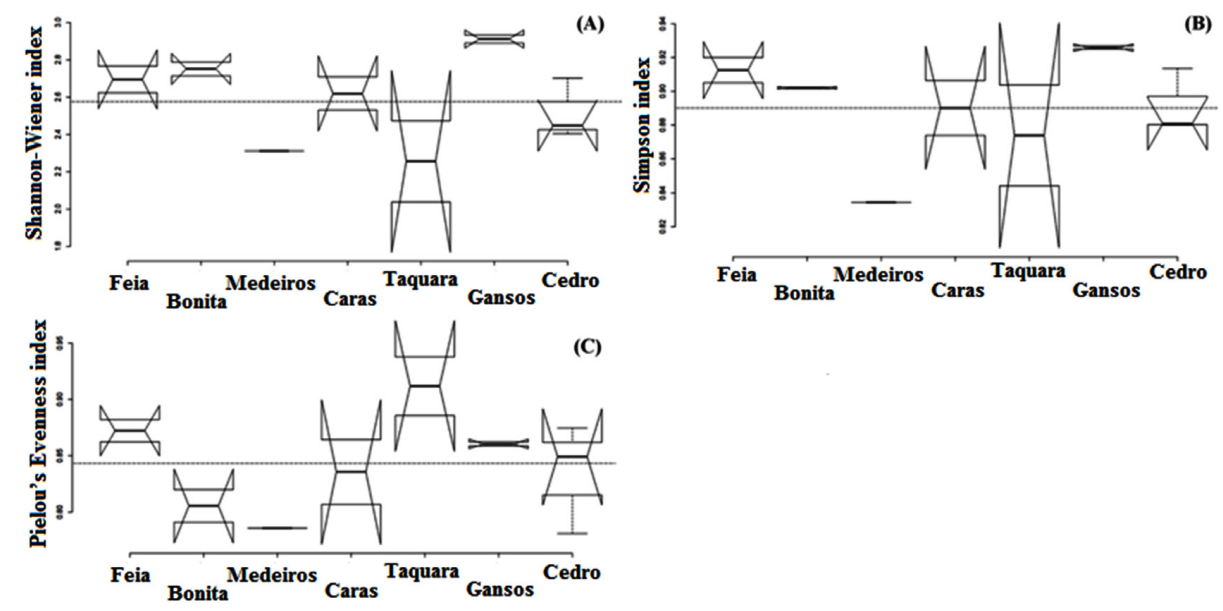

Figure 2. Average values (bold line), maximum and minimum (bars), third and first quartile (box), of the ShannonWiener index (A), Simpson index (B) and Pielou's Evenness index (C) of all sampling points (shallow lakes).

However, the Pielou's Evenness index (Figure 2C) showed a different pattern, where the higher values are found in Taquara, Feia, Gansos and Cedro lakes (below the mean), but the lower values in Carás, Bonita and Medeiros lakes (above the mean).

The mean of specie richness was 23 taxon (range on 13 in Taquara lake to 32 in bonita lakes). The Alona genus shows higher specie richness with 4 taxon (Alona sp., Alona guttata, Alona intermedia, Alona verrucosa). We found the higher richness (number of taxa/ $\alpha$ diversity) in Bonita, Gansos and Carás lakes (above the mean), followed by Cedro, Feia, Medeiros and Taquara lakes, dawn the mean values (One way ANOVA, $\mathrm{F}_{(6,2)}=21,78 ; \mathrm{p}<0.001$; Newman-Keuls test; $\mathrm{p}<0.05$; Figure 3A). In the turnover among taxon in the sampling points
( $\beta$ diversity), we found the higher values in Taquara lake, following by Carás, Cedro and Feia lakes, with the lower values in Bonita, Gansos and Medeiros lakes (PerMANOVA, $\mathrm{F}_{(6,28)}=3,01 ; \mathrm{p}=0.007$; Bonferroni-corrected pairwise $\mathrm{p}<0.05$; Figure 3B)

\subsection{Factors that structure the zooplanckton community}

The CCA (total inertia of 0.355 ) of the abiotic variables and the community exhibited high explanatory power $(87 \%$, inertia of 0.312$)$. Axis 1 of the CCA ordination explained $37 \%$ (inertia of 0.1353 ) of the total variance, while axis 2 explained $29 \%$ (inertia of 0.1062; Figure 4). The structure and composition of zooplankton community changes among sample points (PerMANOVA, $\mathrm{F}_{(6,28)}=1,59$; 


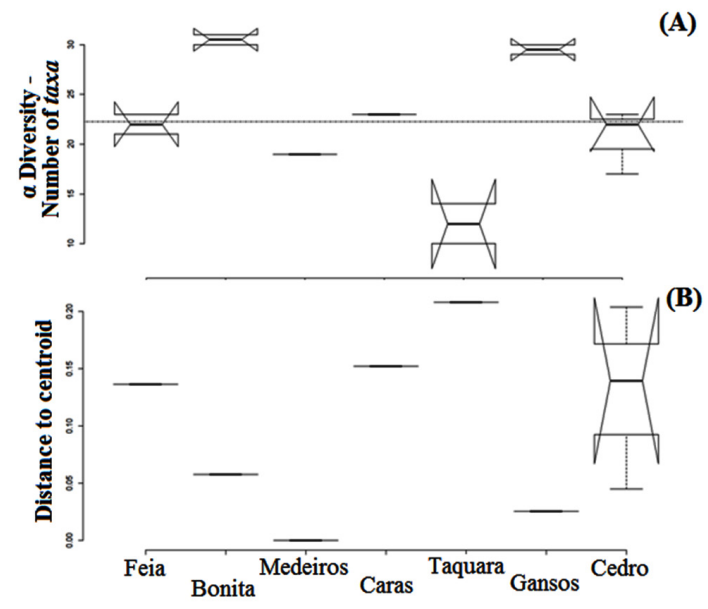

Figure 3. Average values (bold line), maximum and minimum (bars), third and first quartile (box), of the $\alpha$ diversity (A) and $\beta$ diversity (B) in the seven sampling points (shallow lakes).

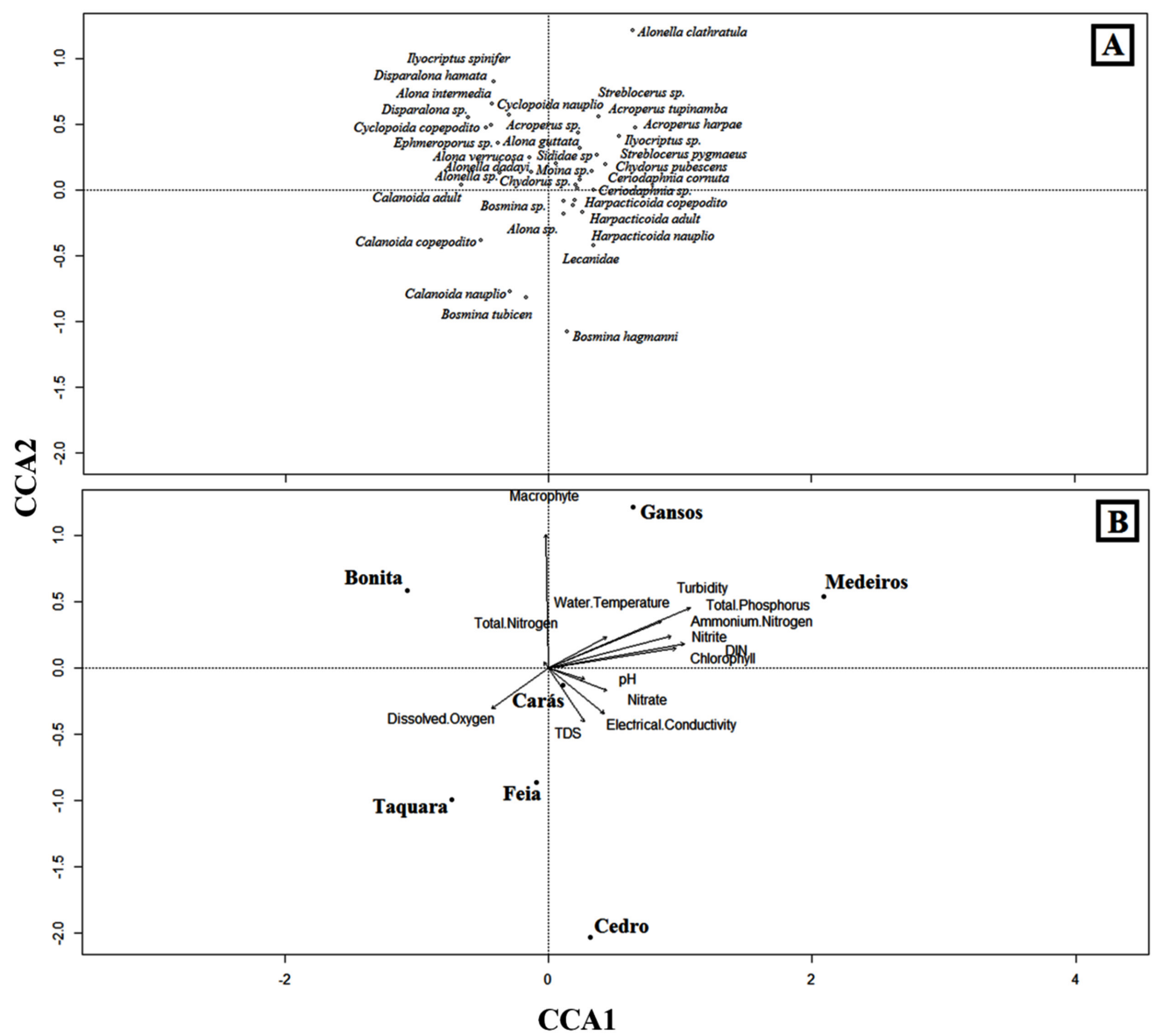

Figure 4. Canonical correspondence analysis of zooplankton community (A) and abiotic variables (B) in the seven sampling points (shallow lakes).

$\mathrm{p}=0.037)$. In all abiotic variables, only dissolved oxygen, percentage of lake covered by macrophytic and $\mathrm{N}$ total were correlated negatively with axis 1 , together with Bonita, Feia and Taquara lakes (Bonferroni-corrected pairwise; $\mathrm{p}<0.05$ ). On the other hand, the dissolved oxygen, $\mathrm{pH}$, electric conductivity, nitrate and TDS (total dissolved solids) correlated negatively with axis 2 (and the others positively), together with Carás, Cedro, Gansos and Medeiros lakes (Bonferroni-corrected 
Table 2. Statistical significance of the correlation between the environmental features and biotic variables extracted from the CCA1 and CCA2 vectors of the Monte Carlo test. Significant values in bold.

\begin{tabular}{lrrrl}
\hline & CCA1 & CCA2 & $\mathbf{r}^{2}$ & Pr(>r) \\
\hline Water.Temp & 0.883 & 0.469 & 0.173 & 0.780 \\
Dissolved.Oxygen & -0.812 & -0.584 & 0.194 & 0.738 \\
pH & 0.956 & -0.294 & 0.057 & 0.920 \\
Electrical.Conductivity & 0.777 & -0.630 & 0.206 & 0.618 \\
Chlorophyll & 0.994 & 0.114 & 0.009 & 0.918 \\
Turbidity & $\mathbf{0 . 9 2 2}$ & $\mathbf{0 . 3 8 6}$ & $\mathbf{0 . 9 4 9}$ & $\mathbf{0 . 0 0 5}$ \\
Ammonium.Nitrogen & $\mathbf{0 . 9 8 5}$ & $\mathbf{0 . 1 7 5}$ & $\mathbf{0 . 7 6 3}$ & $\mathbf{0 . 0 1 3}$ \\
Nitrate & 0.932 & -0.363 & 0.158 & 0.757 \\
Nitrite & 0.969 & 0.248 & 0.643 & 0.181 \\
Total.Nitrogen & -0.577 & 0.816 & 0.002 & 0.996 \\
Total.Phosphorus & 0.925 & 0.380 & 0.602 & 0.276 \\
TDS & 0.554 & -0.832 & 0.166 & 0.652 \\
DIN & 0.989 & 0.149 & 0.671 & 0.195 \\
Macrophyte & $\mathbf{- 0 . 0 2 0}$ & $\mathbf{0 . 9 8 5}$ & $\mathbf{0 . 7 0 6}$ & $\mathbf{0 . 0 4 8}$ \\
\hline
\end{tabular}

pairwise $\mathrm{p}<0.05$; Figure 4). The water turbidity $\left(r^{2}=0.94 ; \mathrm{p}=0.005\right)$, ammonium concentration $\left(r^{2}=0.76 ; p=0.013\right)$ and percentage of lake covered by macrophytic $\left(r^{2}=0.71 ; p=0.048\right)$ were statistically significant correlated with the biotic variables extracted from the CCAs vectors (Monte Carlo test; Table 2). The analysis of the indicator species among the sampling points show high indicator organisms belonged only to Bonita lake (Sum of probabilities $=15.89$; Sum of Indicator Values $=12.14$; Sum of Significant Indicator Values $=1.32$ ). In this sampling point we found Disparalona sp. (Indicator Values $=0.71 ; \mathrm{p}=0.032$ ) and Copepoda Calanoida (Indicator Values $=0.61$; $\mathrm{p}=0.041)$, as indicators.

\section{Discussion}

\subsection{Factors that structure the alpha diversity of zooplankton community}

The alpha diversity (or richness) and abundance (Whittaker, 1960; Legendre et al., 2005) were higher in Bonita and Gansos lakes, facts that explain the higher diversity (Magurran, 2001; Jabiol et al., 2013). This result may be explained by environmental variables (e.g. turbidity and total nitrogen) and biotic interactions (e.g. increase of environmental heterogeneity by macrophytic) that filters and select persistent species within a community, as observed in other tropical lentic systems (Lopes et al., 2014; Rezende et al., 2014). As example, a checklist done for Cladocerans in five shallow lakes evaluated by this study (Bonita, Cedro, Gansos, Joaquim Medeiros and Carás) showed a peculiar composition of this micro fauna, specially associated to environmental condition (shallow systems with a macrophyte dense cover) when they are situated in protected areas (Sousa \& Elmoor-Loureiro, 2012; Anton-Pardo et al., 2015). Therefore, the environmental characteristics should influence diversity (manly by total nitrogen and phosphorus, turbidity and ammonium, as discussed in more detail below), despite other studies do not show a relationship between these variables, highlighting the importance of further research about this matter (Bini et al., 2014; Lopes et al., 2014; Anton-Pardo et al., 2015).

Bonita lake was correlated with total nitrogen in water and the Gansos lake was correlated with total phosphorus, turbidity and temperature in water. These results can be explaining by the increase of system productivity, showing by chlorophyll dates on the shallow lakes (Marleau et al., 2015; Rezende et al., 2016). Also the correlation of most diversity shallow lakes (Bonita and Gansos) whit nitrogen and phosphorus (respectively) in CCA analysis suggest that these nutrients are limiting in savannah lentic systems for the zooplankton communities (Fonseca et al., 2014). Nutrient enrichment also explains the high turbidity by the increase of available ions in the water (Brandimarte et al., 2008). This nutrient enrichment is important due to oligotrophic, shallow and with little fluctuating water level features of these savannah lakes (Junk et al., 2014).

On the other hand, some studies showing that extrapolation of tolerance levels in the niche of some species is a major mechanism disassembling aquatic assemblages at a continental scale (Bini et al., 2014). Therefore, the low concentration of nitrogen and phosphorus associate to higher values of, electrical conduction and TDS (decrease the 
luminosity by increase of turbidity) can decrease the lake productivity level (by chlorophyll), helping to explains the decrease in diversity founded in Feia, Medeiros, Cedro and Taquara lakes. As example, the turbidity (also decreases the temperature and consequently to metabolic rates) and ammonium (increases the toxicity) values were the major factors responsible for structuring the zooplankton community by Xiong et al. (2016). This corroborates the higher diversity and richness in Bonita lake with transparent water (lower turbidity) and lower ammonium content. Another factor that helps the diversity is the presence of aquatic macrophytes that presumably, led to increase niches variation (Jeppesen et al., 1997; Pelicice \& Agostinho, 2006; Choi et al., 2014). In situ experiments, Choi et al. (2014) revealed the tendency to increase zooplankton diversity over habitat heterogeneity provided by aquatic macrophyte in a transparent lake. In contrast, higher alpha diversity was also obtained in Gansos lake, a shallower lake with varied turbidity. This lake remained as a wetland during some periods, preventing the plankton sampling. As a shallower lake, if compared to Bonita lake, submerged and rooted macrophyte tend to predominate and can provide a suitable habitat for colonization by zooplankton, as discussed by Meerhoff et al. (2006). These submerged macrophytes can enhance the refuge of zooplankton threatened by predators, and high phosphorus concentration can indicate food items (Stansfield et al., 1997; Muylaert et al., 2010; Choi et al., 2014).

\subsection{Factors that structure the beta diversity of zooplankton community}

We found low beta diversity in Medeiros lake, configuring a lower species composition turnover and higher stability in the community structure of this lake. In shallow lakes, the dense cover of macrophytes (such as Medeiros lake), permits a large number of littoral and planktonic species to coexist (Guseska et al., 2012; Lopes et al., 2014), decreasing the beta diversity. In the opposite position, Taquara lake obtained a high turnover of species (beta diversity). Although the high environmental condition provided by cover of macrophytes and algae, with wetland and dense riparian vegetation, this lake is situated near to a bridge and a rural area, where groceries, as well as soybean and corn are produced. The lake's sediment was quite muddy and even unstable during this study, with the allochthonous deposition of sediments around the lake. This situation confirms the influence of the environmental quality of the pond derived from the land uses in the area (Lopes et al., 2014; Rezende et al., 2014).

The other lakes (such as Carás, Cedro and Feia), obtained intermediate values of alpha and beta diversities that correspond to the high similarity among their zooplankton communities. The zooplankton of these lakes was closely related to environmental gradient (Carvalho et al., 2001; Xiong et al., 2016) because of similar geography and spatial proximity. The connectivity on aquatic systems is known to increase the similarity in species composition (Durães et al., 2016), decreasing the beta diversity (Lopes et al., 2014; Heino et al., 2015a, b). Nabout et al. (2006) also got similar phytoplankton composition in geographically proximate floodplain shallow lakes, even with different geomorphological characteristics and degrees of human impact (Xiong et al., 2016). Therefore, in deterministic processes based on niche theory, the species have different ecological requirements, leading to different responses to environmental gradients (Heino et al., 2015a, b; Xiong et al., 2016), and increasing the beta diversity in heterogenic systems (Rezende et al., 2014).

The zooplankton communities were dominated by Cladocera, especially by species belonging to typically non-planktonic (Chydoridae). This situation is to be expected in the majority of shallow environments with a developed littoral zone colonized by macrophytes (Fantin-Cruz et al., 2010; Sousa \& Elmoor-Loureiro, 2012). Rotifer species registered in this study belonged to Lecanidae, family inhabiting shallow and littoral areas and often associated with plants (Padovesi-Fonseca et al., 2011; Siddiqi \& Karuthapandi, 2013). There was a relative predominance of young forms of Copepoda and this pattern has been the most common, as observed by López \& Sampaio (2000) and Silveira et al. (2010) in shallow systems. This situation may be the result of predation on the adult forms and its further effect on the development of immature stages to adults.

Another important aspect is that turbidity represented an environmental condition for development of larger filter feeders (Fantin-Cruz et al., 2011), corroborated by the presence and abundance of calanoid copepod in Bonita lake and its absence in Gansos lake. Calanoida is a planktonic group and inhabits open water surface (e.g. Zettler \& Carter, 1986; Lougheed \& Chow-Fraser, 1998); and they represent large filter feeders and herbivores of the zooplankton. Most calanoid species prefer transparent waters with 
small quantity of suspended matter (Zettler \& Carter, 1986; Lougheed \& Chow-Fraser, 1998), explaining its occurrence as indicators of oligotrophy in Bonita lake. Other taxa to present these characteristics were the Disparalona sp. also indicators of oligotrophy in Bonita lake.

\section{Conclusions}

The environmental variables (turbidity and nutrients concentration) and biotic (increase of niches and refuge by macrophytes and dispersion rates by lake geographic proximity) relationship select the persistent species within a community and highlight the importance of environmental characteristics on diversity. The turbidity (decreases the temperature, luminosity and the system productivity) and ammonium (increases the toxicity) values were the major factors responsible for structuring the zooplankton community. On the other hand, nitrogen and phosphorus (increase the productivity) are limiting in savannah lentic systems for the zooplankton. This is observed in Bonita and Gansos lakes (higher diversity) were correlated with low values of turbidity and ammonium, but a higher of nutrients concentration in water (mainly to nitrogen and phosphorus), showing a positive relation with diversity and system productivity. Also, the shallow lakes with higher diversity and richness have a great variety of aquatic macrophytes that increase the variation of niches and refuge against predators, corroborating our first hypothesis. We also observed that shallow lakes with geographic proximity increase the similarity in species composition, decreasing the beta diversity, confirming our second hypothesis. Therefore, we conclude that the deterministic processes (niche theory), due to species have different ecological requirements, are different responses to environmental gradients and increase the diversity in heterogenic lentic systems.

\section{Acknowledgements}

This study was financed by FNMA-Brazil (Edital Nascentes $n^{\circ}$ 2/2005). The authors thank to Luciano Saulo Gonçalves Neiva (In memory) for help with identification, counting and photos of zooplankton.

\section{References}

ALLAN, J.D. Landscapes and riverscapes: the influence of land use on stream ecosystems. Annual Review of Ecology Evolution and Systematics, 2004, 35(1), 257-284. http://dx.doi.org/10.1146/annurev. ecolsys.35.120202.110122.
ALLAN, J.D. Stream ecology: structure and function of running waters. London: Chapman \& Hall, 2007.

ALMEIDA, V., DANTAS, Ê., MELO-JÚNIOR, M., BITTENCOURT-OLIVEIRA, M. and MOURA, A. Zooplanktonic community of six reservoirs in northeast Brazil. Brazilian Journal of Biology = Revista Brasileira de Biologia, 2009, 69(1), 57-65. PMid:19347146. http://dx.doi.org/10.1590/S151969842009000100007.

ANDERSON, M.J., ELLINGSEN, K.E. and MCARDLE, B.H. Multivariate dispersion as a measure of beta diversity. Ecology Letters, 2006, 9(6), 683-693. PMid:16706913. http://dx.doi. org/10.1111/j.1461-0248.2006.00926.x.

ANTON-PARDO, M., ARMENGOL, X. and ORTELLS, R. Zooplankton biodiversity and community structure vary along spatiotemporal environmental gradients in restored peridunal ponds. Journal of Limnology, 2015, 75(1), 193-203.

BINI, L.M., LANDEIRO, V.L., PADIAL, A.A., SIQUEIRA, T. and HEINO, J. Nutrient enrichment is related to two facets of beta diversity for stream invertebrates across the United States. Ecology, 2014, 95(6), 1569-1578. PMid:25039221. http://dx.doi. org/10.1890/13-0656.1.

BOTTRELL, H.H., DUNCAN, A., GLIWICZ, Z.M., GRYGIEREK, E., HERZIG, A., HILLBRICHTILKOWSKA, A. and WEGLENSKA, T. A review of some problems in zooplankton production studies. Norwegian Journal of Zoology, 1976, 24, 419-456.

BOZELLI, R.L. Zooplankton community of Batata and Mussurá Lakes and of the Trombeta River, state of Pará, Brazil. Amazoniana, 1992, 12(1), 239-261.

BRANDIMARTE, A.L., ANAYA, M., SHIMIZU, G.Y., MEIRELLES, S.T. and CANEPPELE, D. Impact of damming the Mogi-Guaçu River (São Paulo State, Brazil) on reservoir limnological variables. Lakes and Reservoirs: Research and Management, 2008, 13(1), 23-35. http://dx.doi.org/10.1111/j.14401770.2007.00359.x.

CARVALHO, P.D., BINI, L.M., THOMAZ, S.M., OLIVEIRA, L.G.D., ROBERTSON, B., TAVECHIO, W.L.G. and DARWISCH, A.J. Comparative limnology of South American floodplain lakes and lagoons. Acta Scientiarum, 2001, 23(2), 265-273.

CHITTAPUN, S., PHOLPUNTHIN, P. and SANOAMUANG, L.-O. Diversity and composition of zooplankton in rice fields during a crop cycle at Pathum Thani province, Thailand. Songklanakarin Journal of Science and Technology, 2009, 31(3), 261-267.

CHOI, J.-Y., JEONG, K.-S., LA, G.-H. and JOO, G.J. Effect of removal of free-floating macrophytes on zooplankton habitat in shallow wetland. Knowledge 
and Management of Aquatic Ecosystems, 2014, (414), 11. http://dx.doi.org/10.1051/kmae/2014023.

DE PAGGI, S.B.J. and PAGGI, J.C. Hydrological Connectivity as a Shaping Force in the Zooplankton Community of Two Lakes in the Paraná River Floodplain. International Review of Hydrobiology, 2008, 93(6), 659-678. http://dx.doi.org/10.1002/ iroh.200711027.

DUDGEON, D., ARTHINGTON, A.H., GESSNER, M.O., KAWABATA, Z.-I., KNOWLER, D.J., LÉVÊQUE, C., NAIMAN, R.J., PRIEURRICHARD, A.-H., SOTO, D., STIASSNY, M.L.J. and SULLIVAN, C.A. Freshwater biodiversity: importance, threats, status and conservation challenges. Biological Reviews of the Cambridge Philosophical Society, 2006, 81(2), 163-182. PMid:16336747. http://dx.doi.org/10.1017/ S1464793105006950.

DUFRÊNE, M. and LEGENDRE, P. Species assemblages and indicator species: the need for a flexible asymmetrical approach. Ecological Monographs, 1997, 67(3), 345-366. http://dx.doi.org/10.1890/00129615(1997)067[0345:SAAIST]2.0.CO;2.

DURÃES, L., ROQUE, F.O., SIQUEIRA, T., SANTOS, A.M., BORGES, M.A. and REZENDE, R.S. Simulating the role of connectivity in shaping stream insect metacommunities under colonization cycle dynamics. Ecological Modelling, 2016, 334, 19-26. http://dx.doi.org/10.1016/j.ecolmodel.2016.04.020.

ELMOOR-LOUREIRO, L.M.A. Phytophilous cladocerans (Crustacea, Anomopoda and Ctenopoda) from Paranã River Valley, Goiás, Brazil. Revista Brasileira de Zoologia, 2007, 24(2), 344-352. http:// dx.doi.org/10.1590/S0101-81752007000200012.

FANTIN-CRUZ, I., PEDROLLO, O., CASTRO, N.M.R., GIRARD, P., ZEILHOFER, P. and HAMILTON, S.K. Historical reconstruction of floodplain inundation in the Pantanal (Brazil) using neural networks. Journal of Hydrology (Amsterdam), 2011, 399(3-4), 376-384. http:// dx.doi.org/10.1016/j.jhydrol.2011.01.014.

FANTIN-CRUZ, I., PEDROLLO, O., COSTA BONECKER, C., DA MOTTA-MARQUES, D. and LOVERDE-OLIVEIRA, S. Zooplankton Density Prediction in a Flood Lake (Pantanal - Brazil) Using Artificial Neural Networks. International Review of Hydrobiology, 2010, 95(4-5), 330-342. http://dx.doi.org/10.1002/iroh.201011205.

FERREIRA, W.R., PAIVA, L.T. and CALLISTO, M. Development of a benthic multimetric index for biomonitoring of a neotropical watershed. Brazilian Journal of Biology = Revista Brasileira de Biologia, 2011, 71(1), 15-25. PMid:21437395. http://dx.doi. org/10.1590/S1519-69842011000100005.

FONSECA, B.M., DE MENDONCA-GALVAO, L., PADOVESI-FONSECA, C., DE ABREU, L.M. and FERNANDES, A.C. Nutrient baselines of Cerrado low-order streams: comparing natural and impacted sites in Central Brazil. Environmental Monitoring and Assessment, 2014, 186(1), 19-33. PMid:23887888. http://dx.doi.org/10.1007/ s10661-013-3351-8.

GRENOUILLET, G., BROSSE, S., TUDESQUE, L., LEK, S., BARAILlÉ, Y. and LOOT, G. Concordance among stream assemblages and spatial autocorrelation along a fragmented gradient. Diversity \& Distributions, 2008, 14(4), 592-603. http://dx.doi. org/10.1111/j.1472-4642.2007.00443.x.

GUSESKA, D., TASEVSKA, O. and KOSTOSKI, G. Zooplankton dynamic of Lake Prespa (Macedonia). Biologia, 2012, 67(5), 939-944. http://dx.doi. org/10.2478/s11756-012-0092-z.

HARDY, E.R. Changes in species composition of Cladocera and food availability in a floodplain lake, Lago Jacaretinga, Central Amazon. Amazoniana, 1992, 7(2), 155-168.

HEINO, J., MELO, A.S. and BINI, L.M. Reconceptualising the beta diversity-environmental heterogeneity relationship in running water systems. Freshwater Biology, 2015a, 60(2), 223-235. http:// dx.doi.org/10.1111/fwb.12502.

HEINO, J., MELO, A.S., BINI, L.M., ALTERMATT, F., AL-SHAMI, S.A., ANGELER, D.G., BONADA, N., BRAND, C., CALLISTO, M., COTTENIE, K., DANGLES, O., DUDGEON, D., ENCALADA, A., GÖTHE, E., GRÖNROOS, M., HAMADA, N., JACOBSEN, D., LANDEIRO, V.L., LIGEIRO, R., MARTINS, R.T., MISERENDINO, M.L., MD RAWI, C.S., RODRIGUES, M.E., ROQUE, F.O., SANDIN, L., SCHMERA, D., SGARBI, L.F., SIMAIKA, J.P., SIQUEIRA, T., THOMPSON, R.M. and TOWNSEND, C.R. A comparative analysis reveals weak relationships between ecological factors and beta diversity of stream insect metacommunities at two spatial levels. Ecology and Evolution, 2015b, 5(6), 1235-1248. PMid:25859329. http://dx.doi. org/10.1002/ece3.1439.

JABIOL, J., BRUDER, A., GESSNER, M.O., MAKKONEN, M., MCKIE, B.G., PEETERS, E.T.H.M., VOS, V.C.A. and CHAUVET, E. Diversity patterns of leaf-associated aquatic hyphomycetes along a broad latitudinal gradient. Fungal Ecology, 2013, 6(5), 439-448. http://dx.doi. org/10.1016/j.funeco.2013.04.002.

JEPPESEN, E., JENSEN, J.P., SØNDERGAARD, M., LAURIDSEN, T., PEDERSEN, L.J. and JENSEN, L. Top-down control in freshwater lakes: the role of nutrient state, submerged macrophytes and water depth. Hydrobiologia, 1997, 342(0), 151-164. http:// dx.doi.org/10.1023/A:1017046130329.

JUNK, W.J., PIEDADE, M.T.F., LOURIVAL, R., WITTMANN, F., KANDUS, P., LACERDA, L.D. and CAMARGO, E. Definição e Classificação das Áreas Úmidas (AUs) brasileiras: base científica para 
uma nova política de proteção e manejo sustentável. In C. N. CUNHA, M. T. F. PIEDADE and W. J. JUNK, eds. Classificação e delineamento das Áreas Úmidas Brasileiras e de seus macrohabitats. Cuiabá: INCT-INAU-EdUFMT, 2014, pp. 13-76. vol. 1.

KOLEFF, P., GASTON, K.J. and LENNON, J.J. Measuring beta diversity for presence-absence data. Journal of Animal Ecology, 2003, 72(3), 367-382. http://dx.doi.org/10.1046/j.13652656.2003.00710.x.

KOSTE, W. Rotatoria Die Radertiere Mitteleuropas bergriindet von Max Voigt-Monogononta. Berlin: Gebrlider Borntraeger, 1978.

KOZLOWSKY-SUZUKI, B. and BOZELLI, R.L. Experimental evidence of the effect of nutrient enrichment on the zooplankton in a Brazilian coastal lagoon. Brazilian Journal of Biology = Revista Brasileira de Biologia, 2002, 62(4B), 835-846. PMid:12659035. http://dx.doi.org/10.1590/S151969842002000500013.

KUMAR, N.J.L., DAS, M., MUKHERJI, R. and KUMAR, R.N. Assessment of zooplankton diversity of a tropical wetland system. International Journal of Pharmacy \& Life Sciences, 2011, 2(8), 983-990.

LANSAC-TÔHA, F., BONECKER, C., VELHO, L., SIMÓES, N., DIAS, J., ALVES, G. and TAKAHASHI, E. Biodiversity of zooplankton communities in the Upper Paraná River floodplain: interannual variation from long-term studies. Brazilian Journal of Biology = Revista Brasileira de Biologia, 2009, 69(2, Suppl), 539-549. PMid:19738961. http://dx.doi.org/10.1590/S151969842009000300009 .

LEGENDRE, P. and LEGENDRE, L. Numericalecology. London: Elsevier, 1998. English edition.

LEGENDRE, P., BORCARD, D. and PERES-NETO, P.R. Analyzing beta diversity: partitioning the spatial variation of community composition data. Ecological Monographs, 2005, 75(4), 435-450. http://dx.doi. org/10.1890/05-0549.

LEIBOWITZ, S.G. Isolated wetlands and their functions: An ecological perspective. Wetlands, 2003, 23(3), 517-531. http://dx.doi.org/10.1672/02775212(2003)023[0517:IWATFA]2.0.CO;2.

LOPES, P.M., BINI, L.M., DECLERCK, S.A.J., FARJALLA, V.F., VIEIRA, L.C.G., BONECKER, C.C., LANSAC-TOHA, F.A., ESTEVES, F.A. and BOZELLI, R.L. Correlates of zooplankton beta diversity in tropical lake systems. PLoS One, 2014, 9(10), e109581. PMid:25330034. http://dx.doi. org/10.1371/journal.pone.0109581.

LÓPEZ, C.M. and SAMPAIO, E.V. Sobrevivência e crescimento larval do pacamá Lophiosilurus alexandri Steindachner, 1876 (Siluriformes, Pimelodidae), em função de três densidades de estocagem em laboratório. Acta Scientiarum, 2000, 22, 491-494.
LOUGHEED, V. and CHOW-FRASER, P. Factors that regulated the zooplankton community structure of a turbid, hypertrophic Great Lakes wetland. Canadian Journal of Fisheries and Aquatic Sciences, 1998, 55(1), 150-161. http://dx.doi.org/10.1139/f97-227.

MAGURRAN, A.E. Ecological diversity and its measurement. London: Chapman and Hall, 2001.

MARLEAU, J.N., GUICHARD, F. and LOREAU, M. Emergence of nutrient co-limitation through movement in stoichiometric meta-ecosystems. Ecology Letters, 2015, 18(11), 1163-1173. PMid:26303749. http://dx.doi.org/10.1111/ele.12495.

MATSUMURA-TUNDISI, T. and TUNDISI, J.G. Plankton richness in a eutrophic reservoir (Barra Bonita Reservoir, SP, Brazil). In H. SEGERS and K. MARTENS (Eds.), Aquatic Biodiversity II. Dordrecht: Springer Netherlands, 2005, pp. $367-$ 378.

MEERHOFF, M., FOSALBA, C., BRUZZONE, C., MAZZEO, N., NOORDOVEN, W. and JEPPESEN, E. An experimental study of habitat choice by Daphnia: plants signal danger more than refuge in subtropical lakes. Freshwater Biology, 2006, 51(7), 1320-1330. http://dx.doi.org/10.1111/ j.1365-2427.2006.01574.x.

MUYLAERT, K., PÉREZ-MARTÍNEZ, C., SÁNCHEZ-CASTILLO, P., LAURIDSEN, T.L., VANDERSTUKKEN, M., DECLERCK, S.A.J., VAN DER GUCHT, K., CONDE-PORCUNA, J.-M., JEPPESEN, E., DE MEESTER, L. and VYVERMAN, W. VYVERMAN, W. Influence of nutrients, submerged macrophytes and zooplankton grazing on phytoplankton biomass and diversity along a latitudinal gradient in Europe. Hydrobiologia, 2010, 653(1), 79-90. http://dx.doi.org/10.1007/ s10750-010-0345-1.

NABOUT, J.C., NOGUEIRA, I.S. and OLIVEIRA, L.G. Phytoplankton community of floodplain lakes of the Araguaia River, Brazil, in the rainy and dry seasons. Journal of Plankton Research, 2006, 28(2), 181-193. http://dx.doi.org/10.1093/plankt/fbi111.

NESSIMIAN, J.L., VENTICINQUE, E.M., ZUANON, J., MARCO, P., GORDO, M., FIDELIS, L. and JUEN, L. Land use, habitat integrity, and aquatic insect assemblages in Central Amazonian streams. Hydrobiologia, 2008, 614(1), 117-131. http://dx.doi.org/10.1007/s10750-0089441-x.

NORLIN, J.I., BAYLEY, S.E. and ROSS, L.C.M. Zooplankton composition and ecology in Western Boreal Shallow-water Wetlands. Hydrobiologia, 2006, 560(1), 197-215. http://dx.doi.org/10.1007/ s10750-005-1185-2.

OKSANEN, J., BLANCHET, F.G., KINDT, R., LEGENDRE, P., MINCHIN, P.R., O'HARA, R.B. and WAGNER, H. Community ecology package: ordination, diversity and dissimilarities. Version 2.0-8. 
Vienna: R Development Core Team, 2008 [viewed 10 Feb. 2017]. Available from: http://vegan.r-force.rproject.org

ORTEGA-MAYAGOITIA, E., ARMENGOL, $X$. and ROJO, C. Structure and dynamics of zooplankton in a semi-arid wetland, the National Park Las Tablas de Daimiel (Spain). Wetlands, 2000, 20(4), 629-638. http://dx.doi.org/10.1672/02775212(2000)020[0629:SADOZI]2.0.CO;2.

PADOVESI-FONSECA, C., GALVÃO, L.D.M. and BATISTA, C.A. Rotifera, Paranoá reservoir, Brasília, central Brazil. Check List, 2011, 7(3), 248-252. http://dx.doi.org/10.15560/7.3.248.

PELICICE, F.M. and AGOSTINHO, A.A. Feeding ecology of fishes associated with Egeria spp. patches in a tropical reservoir, Brazil. Ecology Freshwater Fish, 2006, 15(1), 10-19. http://dx.doi.org/10.1111/ j.1600-0633.2005.00121.x.

REZENDE, R.D.S., GRAÇA, M.A.S., SANTOS, A.M., MEDEIROS, A.O., SANTOS, P.F., NUNES, Y.R. and GONÇALVES JÚNIOR, J.F. Organic matter dynamics in a tropical gallery forest in a grassland landscape. Biotropica, 2016, 1(1), 301-310. http:// dx.doi.org/10.1111/btp.12308.

REZENDE, R.S., SANTOS, A.M., HENKEOLIVEIRA, C. and GONÇALVES JÚNIOR, J.F. Effects of spatial and environmental factors on benthic a macroinvertebrate community. Zoologia (Curitiba), 2014, 31(5), 426-434. http://dx.doi. org/10.1590/S1984-46702014005000001.

SEGERS, H. Annotated checklist of the rotifers (Phylum Rotifera) with notes on nomenclature, taxonomy and distribution. Zootaxa, 2007, 2(1564), 1-104.

SIDDIQI, S.Z. and KARUTHAPANDI, M. A report on Lecanidae (Rotifera: Monogononta) from Andhra Pradesh, India, including six new distribution records with notes on their contemporary taxonomic nomenclature. Journal of Threatened Taxa, 2013, 5(11), 45-56. http://dx.doi.org/10.11609/JoTT. o3095.4556-61.
SILVEIRA, R.D.M.L., PAIVA, L.L.A.R.D. and CAMARGO, J.C. Top-down control in a tropical shallow lake of Northern Pantanal, Brazil. Acta Limnologica Brasiliensia, 2010, 22(4), 455-465. http://dx.doi.org/10.4322/actalb.2011.009.

SOUSA, F.D.R. and ELMOOR-LOUREIRO, L.M.A. How many species of cladocerans (Crustacea, Branchiopoda) are found in Brazilian Federal District? Acta Limnologica Brasiliensia, 2012, 24(4), 351-362. http://dx.doi.org/10.1590/S2179975X2013005000008.

STANSFIELD, J.H., PERROW, M.R., TENCH, L.D., JOWITT, A.J.D. and TAYLOR, A.A.L. Submerged macrophytes as refuges for grazing Cladocera against fish [-3pt]predation: observations on seasonal changes in relation to macrophyte cover and predation pressure. Hydrobiologia, 1997, 342(0), 229240. http://dx.doi.org/10.1023/A:1017091407556.

WHITTAKER, R.H. Vegetation of the Siskiyou Mountains, Oregon and California. Ecological Monographs, 1960, 30(3), 279-338. http://dx.doi. org/10.2307/1943563.

XIONG, W., LI, J., CHEN, Y., SHAN, B., WANG, W. and ZHAN, A. Determinants of community structure of zooplankton in heavily polluted river ecosystems. Scientific Reports, 2016, 6(1), 22043. PMid:26912391. http://dx.doi.org/10.1038/ srep22043.

ZAR, J.H. Bioestatistical analysis. Upper Saddle River: Prentice Hall, 1996.

ZETTLER, E.R. and CARTER, J.C.H. Zooplankton community and species responses to a natural turbidity gradient in lake Temiskaming, OntarioQuebec. Canadian Journal of Fisheries and Aquatic Sciences, 1986, 43(3), 665-673. http://dx.doi. org/10.1139/f86-080.

Received: 10 February 2017 Accepted: 25 August 2017 